\title{
Teams Games Tournament Assisted by Tic Tac Toe Media on the Effectiveness of Students in Learning
}

\author{
Ayatullah Muhammadin Al Fath 1
}

DOI: $10.35445 /$ alishlah.v13i2.784

\begin{abstract}
Article Info
Abstract

Keywords: Cooperative learning; Learning Model; Teams Game Tournament

This study aimed to determine the effectiveness of learning in fifth-grade students at SD Negeri I Wonodadi Wetan through the Teams Games Tournament (TGT) type of cooperative learning model. The use of the Teams Games Tournament (TGT) cooperative learning model with the help of Tic Tac Toe media was chosen because the model was considered capable of growing students' enthusiasm and interest in learning effectiveness. This study uses qualitative research where this study uses analytical techniques consisting of data collection, data collection, and conclusions. Using the TGT model makes students learn from each other, causing students to work together. As for the effect of using the Teams Games Tournament (TGT) type cooperative learning model, there is an interaction between learning methods with high and low learning curiosity on the effectiveness of student learning. Cooperative Learning Method Team Game Tournament can improve learning effectiveness or performance, such as connection ability, activity, learning motivation, and student understanding.
\end{abstract}

Kata kunci: Pembelajaran Kooperatif; Model Pembelajaran; Teams Game Tournament

\begin{abstract}
Abstrak
Tujuan penelitian ini untuk mengetahui efektivitas belajar pada siswa kelas $\mathrm{V}$ di SD Negeri I Wonodadi Wetan melalui penggunaan model pembelajaran kooperatif tipe Teams Games Tournament (TGT). Penggunaan model pembelajaran kooperatif tipe Teams Games Tournament (TGT) berbantu media Tic Tac Toe dipilih karena model tersebut dirasa mampu menumbuhkan semangat dan minat siswa terhadap efektivitas pembelajaran. Penelitian ini menggunakan penelitian kualitatif dimana penelitian ini menggunakan teknik analisis terdiri dari teknik pengumpulan data, menafsirkan data, dan membuat kesimpulan. Hasil penggunaan model pembelajaran TGT membuata siswa saling berkompetisi sehingga menimbulkan siswa yang saling bekerja sama. Adapun pengaruh dari penggunaan model pembelajaran kooperatif tipe Teams Games Tournament (TGT), terdapat hubungan antara metode pembelajaran dengan keingintahuan belajar tinggi dan rendah terhadap Efektivitas belajar siswa. Metode Pembelajaran Kooperatif TGT dapat meningkatkan efektivitas belajar atau kinerja pembelajaran seperti kemampuan koneksi, aktivitas, motivasi belajar dan pemahaman siswa.
\end{abstract}

${ }^{1}$ Universitas Negeri Yogyakarta, Yogyakarta, Indonesia
Email: ayatullahmuhammadin.2020@student.uny.ac.id 


\section{INTRODUCTION}

Education today is one of the basic needs that every human being must meet. Educational programs emphasize the knowledge (cognitive) aspect and emphasize fostering attitudes and developing students' skills. Through education, humans are expected to improve their quality of life to become a developed nation. Classroom learning is an essential part of the curriculum. Providing quality classroom training can lead to quality outcomes. The teacher plays a vital role in the administration of the class in the learning process. The implementation of the learning process is said to be effective if it has reached the specified target. In addition, the quality of education also depends on the teacher or teacher.

In Indonesia itself, there are still problems related to education that cause the quality of Indonesian education to lag. Factors that indicate the lack of quality education in Indonesia include inadequate facilities and infrastructure in some remote areas. There are still teachers who teach not by the educational qualifications they are taking, lagging in learning programs, the high cost of education. The quality of education also has an outstanding impact. The quality of good education is seen from competent educators in their fields. All the factors that exist in the world of education will be overcome by increasing public access to advance education, equitable access to facilities in education, increasing the qualifications of teachers, improve standards in learning, increase the relevance of education, provide some skills to students for capital in the world of work, provide sufficient budget for education and increase teacher creativity through the use of learning models in the learning process. The use of learning models is felt to facilitate the learning process. A good learning process can provide a significant benefit.

The lack of one method can be overcome by other methods to apply different methods in teaching. When choosing a method, different aspects must be considered: the specified learning objectives, time available, number of students, subjects, learning structure, and student conditions, and questions about student success in the learning process. The various methods used can show significant progress on the developmental power of learning. Optimal learning is also able to make learning more colorful.

Learning comes from the word instruction which is widely used in the world of education. Education will affect the holistic flow of cognitive-based on students as a source of activity. Furthermore, words influence the development of technology that is planned to facilitate students to find everything, and the role of the teacher is changed to that of moderator in study activities. Nasution (2017: 186) defines learning in essence as an effort to teach students, and learning design is an arrangement of these efforts so that learning behavior appears. It can be interpreted as follows in an organized condition: the objectives and content of the training are clear, the optimal learning strategy is very likely to contribute to learning.

Currently, the existing learning is still focused on group discussions in general. It is evidenced by the answers from group representatives only, so students who do not understand are understood. Therefore, there is a need for changes in the learning model. Cooperative learning is a learning model that is based on constructivism theory. According to Fathurrohman (Gunarta, 2018:113), the cooperative learning model is a learning model that seeks to achieve the goals of each individual, which in this case is the student to obtain better learning outcomes. Cooperative learning means that learning together learns from each other and ensures that all group members achieve a predetermined goal or task. This cooperative learning is based on the understanding and thinking of students in difficulties when discussing in small groups with friends. Cooperative learning is structured to increase student engagement, provide students with collective decision-making and leadership experiences, and learn and interact with students from different backgrounds. This problem also occurs in elementary schools because various factors such as learning are still focused on the teacher in front and the completion of group discussions. Only a few students are active, not all. Moreover, learn and interact with students from different backgrounds. 
The TGT learning model is a cooperative model where students are placed in teams with heterogeneous abilities to compete in in-game tournaments. Judging from the two opinions, it can be concluded that the Teams Games Tournament is a learning group or team that works together to compete in games or games. Learning activities with games designed in TGT type cooperative learning allow students to learn more relaxed besides fostering responsibility, honesty, cooperation, healthy competition, and student involvement. Cooperative learning means students work together in groups and achieve their individual and group learning goals through peer feedback and discussion. During cooperative learning, students share their knowledge and learn from others in an organized and structured way, while instruction focuses on stimulating, coordinating, and encouraging interaction among students (Shimzoe and Aldrich, (Munir, 2018: 2). Because students have to find solutions in class with their peers, they are more aware of how well they are doing than other students. There is also more incentive to read the course material before class starts. Students are no longer passive but actively learn and learn how to manage their learning instead of expecting to be spoon-fed.

Cooperative learning directly and expands the mutual affiliation before avoiding anger and misunderstandings that can generate hostility, such as socializing in society. Cooperative learning has many benefits for students and teachers. For example, it is helping students to make progress in deep learning and critical thinking. They develop social and communication skills that may be of use to them after graduation. Similarly, teachers can use cooperative learning classroom time to pay attention to and reflect on student learning. Some use of peer assessment can reduce the burden of grading and, at the same time, make the timing process more transparent for students.

Teams-Games-Tournaments (TGT) was initially created by David Doris and Kate Edwards (Salam, 2015: 4). This is a kind of cooperative learning method. Students compete with other team members for team points. Students compete in at least three "table tournaments" against others with similar records in mathematics. After that, the procedure changes the table assignment to keep the competition fair. The winner in each tournament brings the same points to result to his team. Regardless of which table it is, this means that high achievers and low achievers have an equal chance of success. High-performing teams earn team rewards. For this reason, applying the TGT learning model will help improve the learning process and student learning effectiveness in learning.

Learning at SD N 1 Wonodadi Wetan tends to occur individually, where the teacher is the learning center. So that students show a lack of enthusiasm in learning, students often have difficulty answering questions that the teacher often asks. To activate this, the teacher uses the lecture method, which involves students discussing in class. Nevertheless, this strategy is not very effective, even though the teacher has encouraged students to participate. The Teams Games Tournament type of cooperative learning model is very suitable if applied in the learning process at SD N 1 Wonodadi Wetan. Students often have difficulty answering questions that the teacher often asks. To activate this, the teacher uses the lecture method, which involves students discussing in class.

Games are one of the media aids in learning, with game aids students do not become bored during the learning process. Tic Tac Toe is one of them as a media tool in learning that is interesting to play. Garry (2019:2) Tic Tac Toe game is a 9 x 9 board game or board game where players have to take turns scoring. There is also another opinion from Chrisdaniar (2020:21). Game Tic Tac Toe is a picture game that forms a box of nine boxes. The benefit of this game is to train students in strategies for playing, care, concentration, social skills, and participation in active learning. From both opinions, tic tac toe media is a board game where every team member participates. This game is suitable if combined with the Teams Games Tournament model because both work together in groups or teams. The Teams Games Tournament (TGT) model and this Tic Tac Toe game will be fun if they are arranged in learning activities. Learning activities will be packaged in group discussions, and they will be responsible for themselves and their groups. In addition, the game Tic Tac Toe will make students cooperate in competition. 
With the ultimate goal of improving education, identifying the attributes that contribute to teacher effectiveness has been and continues to be necessary. For this reason, the empirical examination of teacher characteristics potentially related to teacher effectiveness has sparked considerable interest over the last few decades. Teaching is effective when it enables student learning. Bardach (2020:2) defines teacher effectiveness as the effect of high-quality teaching on student achievement. We regard high-quality teaching as a dynamic and interactive process of creating, fostering, adapting, and negotiating a learning environment where all students are supported in activities that have excellent opportunities to enhance learning.

Other researchers have done a previous study about the implementation of TGT (Gunarta, 2018; Garry, 2019; Chrisdaniar, 2020). The benefit of the learning method is to improve the quality of student learning outcomes. This research is based on research (Putra, 2015:152) about Experimentation of Cooperative Learning Model Type Teams Games Tournament (TGT) Assisted by Cabri 3d Software in Review of Students' Mathematical Connection Ability. In this study, the TGT model uses an innovative joint training model.

\section{METHODS}

This research is qualitative because the problems are related to humans, which fundamentally depend on observation. According to Cristian Julmi (2019: 2), qualitative is the uniqueness of each situation recognized, the quality of the researcher, qualitative does not claim that findings from certain situations can be transferred to other situations. The focus is exploration, enlightenment, awareness, and intersubjective agreement to develop an ingeniously rich understanding of (creative) actions, words, events, products, places, or people. The researcher is at the center of the research process, and the quality of data collection, description, and interpretation determine the quality of the research conducted.

This research has conducted at SD N 1 Wonodadi Wetan. The selection of this place is based on various considerations. This study uses the concept of phenomenology. This phenomenological concept explains relationships and estimates of communicating with others and making sense to others. Research conducted at SD N 1 Wonodadi Wetan also requires relationships and estimates to communicate with others. The researchers took research subjects from fifth-grade students and fifth-grade teachers. The resource persons from fifth grade were 6 students consisting of 2 girls and 4 boys. Data collection techniques in qualitative research data collection are based on observation and documentation. This credibility test aims to prove that the data or information obtained is based on the truth value. The credibility test in this qualitative research was carried out by triangulation of sources used to obtain valid data. Data analysis used is data reduction, data presentation, and concluding. The data analysis is reinforced by the opinion of Raco (2018: 121). Data analysis means systematic regulation of interviews and observations, interpreting them and generating new thoughts, theories, or ideas. These are called results or results. Qualitative analysis means research and searches for themes, models, concepts, perspectives, and understanding.

\section{FINDINGS AND DISCUSSION}

Data collection is carried out offline in public places such as prayer rooms, hamlet offices, and teachers' homes. For offline research using the observation method, as many as 6 students were observed before and after being treated with the Teams Games Tournament (TGT) suitable method with Tic Tac Toe assisting media how the effectiveness of student learning in participating in learning. In addition, observations of teachers are carried out to find out how teachers manage to learn to take place. The current learning outcomes are complicated. Therefore teachers must be creative in using various methods. Various information was obtained during the data collection process, such as using the TGT type cooperative method, which was very suitable for being carried out at SDN 1 Wonodadi Wetan with a few students. In the implementation itself, the teacher can master learning because it is easy. Reinforced by research conducted by Salam et al. (2015), these 
results show that the TGT experimental group students achieved more learning outcomes than the lecture-based control group students. Attitudes towards mathematics differed to a certain degree of positivity in the TGT experimental group. Cooperative models give color to conventional learning where students play an active role in the learning process. In addition to learning, students can play to attract students' attention in participating in learning. In addition, the results of interviews with teachers concluded that the cooperative model could increase student effectiveness through Tic Tac Toe aids.

\section{The Process of Making Tic Tac Toe Media}

The use of Tic Tac Toe game aids makes work and activities efficient. That way, it can cut time and can also reduce the energy expended. Garry (2019:2) Tic Tac Toe game is a 9 x 9 board game or board game where players have to take turns scoring. The first player to successfully arrange four consecutive marks horizontally, vertically, or diagonally will be declared the winner of the game. In making this first game, prepare paper, scissors, a ruler, and a pen. Second, make the paper into 9 rectangular sections. Third, divide the six rectangular boxes and three boxes, each filled with symbols $\mathrm{X}$ and $\mathrm{O}$. Fourth, make a rectangular grid board by dividing the box into nine parts. All five Tic Tac Toe boards are ready to go.
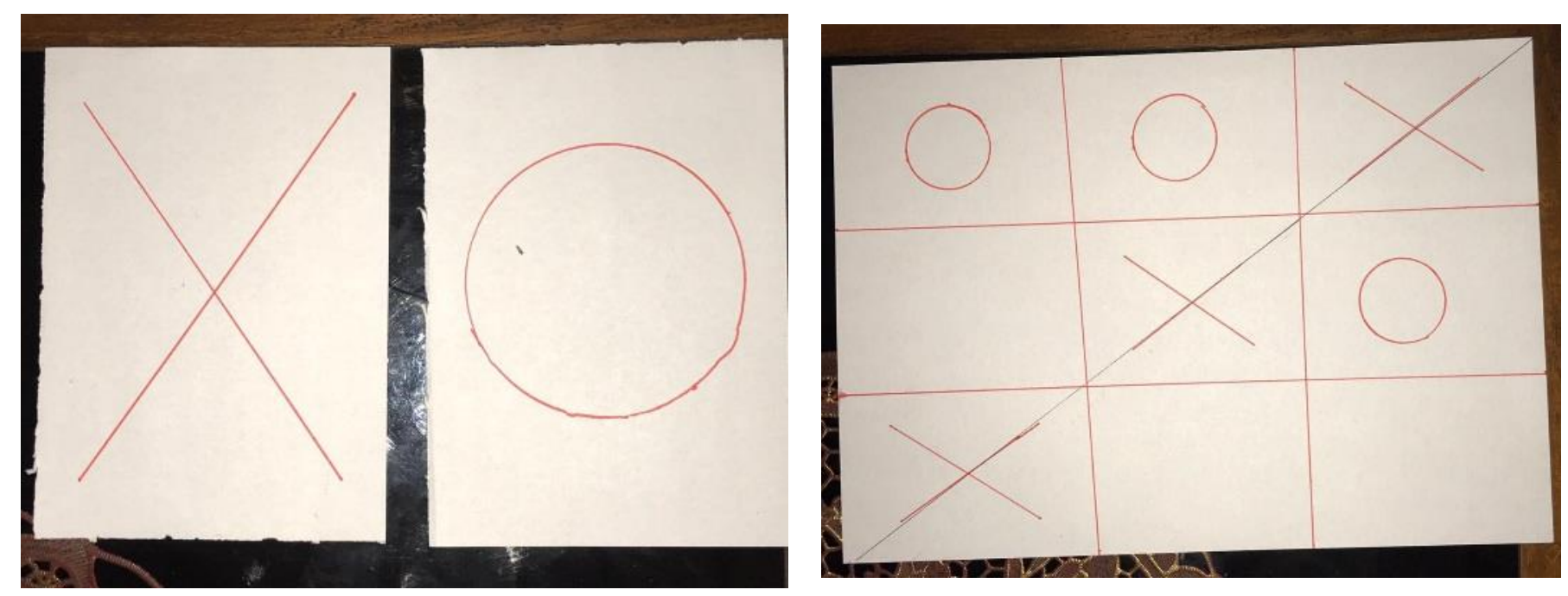

Figure 1. Tic Tac Toe Media

\section{Use of Media in Learning}

Teams Games Tournament (TGT) cooperative learning model is used in offline learning. Some steps in implementing this model are; (1) Make groups, (2) Make student activity sheets, (3) Tell what to do with the team, (4) Evaluate, (5) Make individual and group scores, (6) Giving awards or appreciation. TGT with Tic Tac Toe media is as the following steps (1) The teacher divides the students to form a homogeneous group of 2-3 groups. (2) The teacher divides the students into tournament tables. (3) The teacher reads the questions that each group will answer. (4) The teacher explains the rules of the game at each tournament table. (5) The teacher provides an opportunity for each tournament group to play a game. (6) The teacher gives an X or O mark to the group if the answer is correct, and if the answer is wrong, it will not get the mark. (7) The teacher asks the student to paste it on the board that has been provided. (8) The teacher gives a score/point according to the number of question cards that have been successfully answered. (9) The teacher gives group awards to the group that gets the highest score/point. The material used in the observation is thematic learning theme 6. Through the Teams Games Tournament (TGT) type cooperative learning model, this model is very effective when applied to the learning process,

There is an effect of using the TGT learning method on the effectiveness of student learning. Students are more active in learning, and the learning model is easy to use. The TGT learning model 
can attract students to learning games to not be saturated and rigid. The TGT learning model makes students compete with each other, causing students to work together.

\section{Learning Evaluation Results}

The Teams Games Tournament (TGT) cooperative model with Tic Tac Toe media, which is straightforward to operate, can attract students' interest in participating in offline learning. The Teams Games Tournament type of cooperative learning model used in self-study can be in the form of a Tic Tac Toe game that greatly influences student learning effectiveness. The results of the data analysis of learning observations of teacher activities were triangulated with an interview. Before learning begins, the teacher has made preparations starting from preparing lesson plans, Tic Tac Toe media, and the material to be delivered. At the time of offline implementation, the teacher has taken steps systematically according to the lesson plans prepared previously, starting from greetings, praying, giving apperception, and giving goals before learning activities begin. During the offline implementation, the teacher prepares some of the equipment used, such as paper and a table, by borrowing a place at the village hall or hamlet office. Using the classroom is not allowed. This offline implementation is carried out two times a week and uses Tic Tac Toe media. The use of the Teams Games Tournament type of cooperative learning model does have a positive impact on the interests and desires of students in participating in learning. The cooperative model can provide collaboration and variety (Salam, 2014:4).

Learning is said to be effective if it meets the objectives of learning. If one is not met, then learning is not effective and affects learning outcomes. Learning outcomes make benchmarks in the learning process and can provide evaluations in the learning process so that problems and solutions can be identified in the future. Currently, the method used is generally given that there is no new, more promising breakthrough. The use of the new method is expected to be an alternative in modern learning. Teachers play a key role in helping their students become balanced individuals and cultivate personal and intellectual qualities for the twenty-first century, such as critical thinking, creativity, independence (e.g., self-regulation), and communication skills (i.e., language competence). Yung (2020:2) argues that social norms dominated by performance goals constrain school teachers.

Various benefits resulting from the implementation of pure TGT and other Tic Tac Toe-assisted TGT media were provided. The TGT type cooperative model using Tic Tac Toe assistive media can teach students to communicate with others (Sholihah, 2016: 48). That way, apart from learning, students also get social learning. Although they vary in terms of product impact, both can improve student learning outcomes or realization at all levels. Based on the results of observations and interviews, it can be concluded that various benefits affect the use of the Teams Games Tournament (TGT) type of learning model in the learning process. The most important benefit of the generalization results is that implementing Teams Games Tournament (TGT) ineffective learning improves the quality of the process and learning outcomes. By improving the learning process, the effectiveness of student learning will also be better. Specifically, the improved variables were learning effectiveness, student logging ability, student activity, motivation, and understanding. In addition, this study also found that learning TGT assisted by Tic Tac Toe media or given variations was better than pure TGT.

\section{CONCLUSION}

The Teams Games Tournament (TGT) cooperative learning model with Tic Tac Toe assisting media is obtained. There is an effect of using the learning method with TGT on the effectiveness of student learning. Students are more active in learning, and the learning model is easy to use. The TGT learning model can attract students in learning games not to be saturated and rigid. The TGT learning model makes students compete with each other, causing students to work together. The most important benefit of the generalization results is that implementing the Teams Games 
Tournament (TGT) in effective learning improves the quality of the process and learning outcomes. By improving the learning process, the effectiveness of student learning will also be better. Specifically, the improved variables were learning effectiveness, student logging ability, student activity, motivation, and understanding. Other than that, This study also found that learning TGT assisted by Tic Tac Toe media or given variations was better than pure TGT. Students will be more active in learning by applying the Teams Games Tournament (TGT) type cooperative model using the Tic Tac Toe media. Besides that, it impacts learning outcomes that were originally only discussions but with the help of media providing high learning success. The use of this learning model is more exciting and creative, which impacts learning effectiveness. Teachers should be more creative in carrying out learning by optimizing existing resources. That way, students can follow learning with pleasure and can increase learning effectiveness.

\section{REFERENCES}

Aras, A. 2018. The Effectiveness of the TPS-TGT Cooperative Learning Model in Mathematics Learning in Class VIII SMPN 1 Makassar. Al-Ishlah: Journal of Islamic Education, 16(2), 119127.https://doi.org/10.35905/alishlah.v16i2.757

Bardach, L., \& Klassen, RM. 2020. Smart teachers, successful students: Systematic review of the literature on teacher cognitive abilities and teacher effectiveness, Hong Kong: Review of Educational Research, pp. 1-10. doi:10.1016 / j.edurev.2020.100312

Chrisdaniar, Cempaka Sari, et al. 2020, The Influence of Jigsaw Models Aided by Tic Tac Toe Game on Activities and Learning Outcomes, Lampung: Journal of Bioteredication: Wahana Expresi Ilmiah, Vol 8, Pages 19-26, doi: 10.2396o/jbt.v8.i1. 03

Garry, MH; Yamasari, Y; Nugroho, SMS; \& Purnomo, MH. 2019. Design and Implementation of Serious Game "Tic Tac Toe Math". International Conference on Computer Engineering, Networks, and Intelligent Multimedia (CENIM), pp. 1-6, doi: 10.1109 / cenim48368.2019.8973336

Gumilang, Galang Surya. 2016. Qualitative Research Methods In The Field Of Guidance And Counseling. Journal of Counseling Focus, vol 2, pp. 144-159, https://doi.org/10.26638/jfk.218.2099

Gunarta, I Gd. 2018. The Effect of TGT Learning Model Assisted by Question Card Media on Science Learning Outcomes. Buleleng, Journal of Pedagogy and Learning, vol 1, pp. 112120,http://dx.doi.org/10.23887/jp2.v1i2.19338

Julmi, Cristian. 2019. Research: Qualitative. Hagen : Reference Modules in Neuroscience and Biobehavioral Psychology, pp. 435-441, https://doi.org/10.1016/B978-0-12-809324$5.23678-X$

Liao, Hongjing, et al. 2018. Credibility Techniques Reported in Higher Education An Evaluation Study Using Qualitative Methods: A Blended Research. Beijing: Program Evaluation and Planning, vol 68, pp. 157-165,https://doi.org/10.1016/j.evalprogplan.2018.03.005

Nasution, Wahyudin Nur. 2020. Learning Planning: Understanding, Objectives And Procedures, Medan: Journal Of Education, vol, pp. 185-195, http://repository.uinsu.ac.id/5341/1/

Putra, Ganda, Fredi. 2015. Experimental Cooperative Learning Model Type Teams Games Tournament (TGT) Assisted by Cabri 3d Software in Review of Students' Mathematical Connection Ability, Lampung: Al-Jabar: Journal of Mathematics Education, pp. 143-153, https://doi.org/10.24042/ajpm.v6i2.43

Raco, Jozef. 2018. Qualitative research methods: types, characteristics and advantages, Jakarta: PT Grasindo.

Ramadhani, Putri, Widya, et al. 2020. Application Of Cooperative Learning Model Type Teams Games Tournaments (Tgt) With Ultpygo Learning Media To Improve Student Mathematics Learning Outcomes. Mandar. Scientific Journal of Mathematics Education, vol 5, pp. 211230. DOI: 10.26877 jipmat.v5i2.5480

Rosnah, R. 2015. Application Of Cooperative Learning Type Of Games Tournaments Team To Increase Mathematics Learning Outcomes About Summary And Reduction Of Number In Class 1 Students Of Sd Muhammadiyah 2 Parepare. Al-Ishlah: Journal of Islamic Education, 13(2), 144-177. https://doi.org/10.35905/alishlah.v13i2.499

Salam, Abdus; Hossain, Anwar; Rahman, Shahidur. 2015. Effects of using Cooperative Teams Games Tournaments (TGT) Mathematics Learning Techniques in Bangladeshi Secondary Schools, 
Chittagong: Malaysian Journal of Educational Technology, pp 35-45, http://dx.doi .org/10.17583/redimat.2015.1519

Victoria, Jennifer Rebecca; Matin; Rochanah; Kemal, Isthifa. 2021. Pengaruh Budaya Organisasi dan Komunikasi Terhadap Mutu Layanan SMP Negeri Di Kecamatan Peanggrahan Jakarta Selatan. Visipena, 12 (1), pp. 1-16. https://ejournal.bbg.ac.id/visipena/article/view/1461

Veloo, Arsaythamby; Chairhany, Sitie, 2013. Fostering student attitudes and achievements in using team-game-tournament probability, Sintok: Social and Behavioral Sciences. page 59-64 https://doi.org/10.1016/j.sbspro.2013.09.152

Yung, KW-H. (2020). Comparing the effectiveness of cram school tutors and school teachers: A critical analysis of student perceptions. York: International Journal of Educational Development, pp. 1-21. doi:10.1016 / j.ijedudev.2019.102141 